DOI: $10.1515 /$ pof-2017-0023

VOLUME 9, ISSUE 3, 2017

ISSN: $2036-5438$

\title{
The Spanish vision of Canada's Clarity Act: from idealization to myth
}

by

Francisco Javier Romero Caro*

Perspectives on Federalism, Vol. 9, issue 3, 2017 


\begin{abstract}
Since it was passed, the Clarity Act has been at the core of any secessionist debate in Canada and abroad. Although contested at home, the Clarity Act has earned worldwide prestige as the democratic standard that must be observed when a secessionist debate arises. In the last fifteen years Spain has experienced successive debates about the need to establish a mechanism of popular consultation to address secessionist claims in the Basque Country and Catalonia. Most political actors in favour of such consultations have expressed their will to import the Canadian Clarity Act as a tool to settle disputes on how to conduct a referendum. However, this deification of the Canadian example is, for the most part, based on a misreading of the Secession Reference, only taking into account certain passages while ignoring others. The emphasis tends to be made on the quantitative clear majority test, disregarding other factors. Hence, the aim of this paper is to study the causes of this deification of the Clarity Act in Spain, and its influence on the treatment of secessionist claims that the country is currently experiencing.
\end{abstract}

\title{
Keywords
}

secession, referendum, Clarity Act, Canada, Quebec, Spain, Catalonia 


\section{Introduction}

Constitutional interpretation is not an easy task, and particularly so when courts have to deal with what Dworkin refers to as hard cases. ${ }^{I}$ In these situations, when the choice of norm to apply is not clear, or when there are legal vacuums, resorting to foreign experiences can shed some light on the issue and help legal operators to solve the case.

Facing a secessionist challenge that puts into question the unity of the state is, without any doubt, one of the hardest cases on which a Court might have to decide. Most Constitutions are silent on the matter, while some include clauses that declare the indissoluble character of the nation and the indivisibility of the territory. ${ }^{\text {II }}$ Therefore, the lack of positive legal materials to inform Court's decisions poses a big challenge that might be solved by referring to the practical wisdom of foreign judgments (Choudhry 2006: 4).

Although Chouhdry focuses his approach on judges and tribunals, the migration of constitutional ideas also has an impact in the political arena. This migration might not just be between courts, but also from one Parliament to another. Secession is a complex matter that in its own intrinsic nature combines both the legal and the political (Mancini 2012: 483-487); ${ }^{\mathrm{III}}$ hence, any answer to this problem has to include both elements.

Since the restoration of democracy in 1978, Spain has experienced several secessionist claims, with those coming from the Basque Country and Catalonia having a higher degree of intensity. The Spanish constitutional framework does not contemplate the possibility of holding a referendum to address such claims. This possibility has been rejected by the Constitutional Court according to article 2 of the Spanish Constitution, which affirms that sovereignty resides with the Spanish people and, as a consequence, not with the Autonomous Communities. ${ }^{\text {IV }}$

Regardless of this theoretical consideration about the indivisibility of sovereignty, some political actors have turned their attention to the Canadian experience in order to find a legal framework to address these secessionist claims. After the narrow victory of the 'NO' camp in the 1995 referendum, the Canadian federal government decided that it was time to clarify the ground rules governing secession. Following the Reference Re Secession of Quebec, ${ }^{V}$ the Clarity Act was passed in 2000 with the aim of resolving some of the uncertainties created by the Supreme Court Reference. 
Although contested by Quebec's sovereigntists, and also by some domestic and foreign scholars, ${ }^{\text {VI }}$ the Clarity Act has earned prestige worldwide as the democratic standard that must be observed when a secessionist debate arises, and Spain is no exception. In the last fifteen years, Spain has gone through several debates on the need to establish a mechanism of popular consultation, to address secessionist claims in the Basque Country and Catalonia. Most political actors in favor of these consultations have expressed their will to adopt the Canadian Clarity Act as a tool for settling disputes over how to conduct a referendum. ${ }^{\text {VII }}$

If a bill such as the Clarity Act were to be implemented in Spain, would it help clarify the rules governing secession, reducing current tensions, or on the contrary would it make secession more likely? The Canadian example is a good lens through which to look, but it remains to be seen whether the consequences might be the same as on the other side of the Atlantic.

\section{The Clarity Act in the Canadian constitutional system: a matter of dispute}

In 1995 the unity of the Canadian federation was in question. The referendum on sovereignty was the epilogue of a period of tensions -a "constitutional odyssey" in Russell's words- between Quebec and the federal government that started in 1982 with the patriation of the Constitution without the consent of Quebec's National Assembly and continued with the failure of the constitutional rounds of Lake Meech (1987) and Charlottetown (1992). ${ }^{\text {VIII }}$ The 'NO' camp won by a margin of less than 55,000 votes (about $1.1 \%$ of the electorate), with the highest turnout to date in the history of the province of $93.52 \%$.

This near-death experience led the federal government to refer the matter of the unilateral secession of Quebec to the Supreme Court. After years of constitutional disillusionment, the Supreme Court was called to settle the issue and decide if Quebec had a right to secede under domestic or international law. ${ }^{\text {IX }}$ In its reference the Supreme Court enlarged on the Constitution, which was described as a living tree, ${ }^{\mathrm{x}}$ by identifying a series of unwritten rules that include, "the global system of rules and principles which govern the exercise of constitutional authority in every part of the Canadian state". XI The Court 
highlighted four fundamental principles: federalism, democracy, constitutionalism and the rule of law and respect for minorities. These principles work in symbiosis, meaning that none of them can trump or exclude the others. ${ }^{\mathrm{XI}}$

The operation of these overlapping principles allowed the Court to conclude that Quebec had no right to unilaterally secede from Canada under domestic or international law. ${ }^{\text {XIII }}$ Nevertheless, the interaction of the same principles generated a duty to negotiate in good faith in the event of a clear expression of will of the people of Quebec that can only be derived from a clear majority on a clear question as a result of a qualitative evaluation. ${ }^{\text {XIV }}$ As Tierney (2004: 263) notes, the Court's conception of the term "unilateral" was very narrow, being understood as secession without prior negotiations. This consideration, together with the principles of federalism and democracy, resulted in the creation of an obligation to negotiate in good faith the practicalities of secession, as the rest of Canada could not refuse to enter these negotiations after a clear expression of the desire to pursue secession from the population of a province. ${ }^{\mathrm{Xv}}$

With the intention of giving legal entrenchment to the Secession Reference, the federal government introduced the Clarity Act. ${ }^{\mathrm{XVI}}$ According to Stéphane Dion, the Crown Minister responsible for the act, the bill was needed because the government of Quebec had refused to commit itself to the Court's opinion (Dion 2000: 21). In Dion's view, the interpretation of the Secession Reference made by the Parti Québécois (PQ) was incomplete. It merely focused on the obligation to negotiate, disregarding the notions of a clear majority and a clear question. The preamble of the bill stated that its purpose was to clarify the circumstances under which the government of Canada would enter into negotiations after a provincial referendum on secession. For that reason, the Clarity Act set the rules that must be observed before the federal government enters into any kind of negotiations with a province that wants to secede. According to section 1, the House of Commons has 30 days after the official release of the question to determine whether it is clear. In this process, the Commons would have to consider if the question would result in a clear expression of the will of the people of the province on whether the province should cease to be part of Canada. It must be noted that the Supreme Court did not greatly elaborate on what it understood as a clear question. It merely stated that it should be free of ambiguity and that it was a matter for the political actors to determine. ${ }^{\text {XVII }}$ 
In addition, the federal government also limited the options that could be presented to the electorate, by establishing two types of questions that would not satisfy the clear expression of will requirement of the Act. ${ }^{\text {XVIII }}$ This provision had the intention of preventing the federal government from entering into negotiations following questions such as those used in the 1980 and 1995 referendums (Haljan 2014: 367-368). It was also influenced by opinion poll data suggesting that there was an important degree of confusion among the electorate about what a victory of the 'YES' camp would actually have meant (Keating 2001: 98-101). In this regard, Murkens (2002: 52) questioned if this provision reflected the opinion of the Supreme Court, for the Reference contained no mention of a prohibition of asking about future arrangements with the rest of Canada. ${ }^{\mathrm{XIX}}$ But, as this issue was for the political actors to determine, nothing prevented the federal government from defining the clarity of a question according to these parameters.

In respect of the majority needed in any referendum, the Clarity Act established that the House of Commons should take into account the size of the majority of valid votes cast in favour of the secessionist option, the percentage of eligible voters voting in the referendum and any other matters or circumstances it considered relevant. The Clarity Act did not establish any threshold or minimum level of support required to consider that the result constituted a clear expression of the will to secede. The Court left the issue of the clarity of the majority for the political actors to determine, but it made two important remarks that need to be highlighted. The first one is that the clear majority has to come from a qualitative evaluation; ${ }^{x}$ the second was that democracy, and the Canadian constitutional system, are more than simple majority rule. ${ }^{\mathrm{xxI}}$ From these two premises it can be inferred that a simple majority could not be considered to constitute a clear majority, and that other factors such as the total number of voters or the territorial distribution of votes also need to be taken into account.

As mentioned above, there have been competing interpretations of the opinion of the Court in the Secession Reference between federal and provincial governments (Dumberry 2015: 370-379). In response to the Clarity Act -which made it almost impossible to achieve secession under Canadian law (Pelletier 2001: 526-527)- the National Assembly of Quebec enacted Bill 99, containing Quebec's interpretation of the Secession Reference. ${ }^{\text {XxII }}$ It conferred the inalienable right to freely decide the political regime and legal status of Quebec on the Quebec people, with no external condition having effect on a referendum 
unless determined by Quebec institutions. Bill 99 also stated in section 4 that the winning option would be the one that obtained $50 \%+1$ of the votes cast. Despite this, Monahan (2000: 4-5) recalls that there seemed to be a feeling among Quebeckers that a clear majority was needed to be able to proceed with secession.

As we can see, some provisions of Bill 99 directly conflict with the regulation made by the federal government in the Clarity Act. Although this controversy was referred to the courts years ago, thus far no ruling has been issued. ${ }^{\text {XXIII }}$ To date, a third referendum is not on the agenda, as the PQ has committed itself not to hold one if they return to power as the winning conditions are far from being a reality. ${ }^{\mathrm{xIV}}$

\section{The Spanish vision of the Clarity Act}

\subsection{The process of idealization}

The Canadian example has become a common recourse in the Spanish political arena in the last ten to fifteen years. The 5,686 kilometers that separate Ottawa from Madrid, together with the different cultural, political and constitutional realities of both countries, have not been an impediment for the Canadian model to become configured as a leading exemplar in respect of secessionist claims. Interest in the Canadian model came firstly from academia, where scholars mainly focused on two particular features of the Canadian constitutional system: the role of multiculturalism, ${ }^{\mathrm{xxV}}$ and the Quebec question, being the latter the element that has had the biggest impact on the Spanish political landscape. ${ }^{\mathrm{XxvI}}$

Interest in the Canadian experience switched to the political arena following the 1995 referendum. The referendum and the subsequent reference issued by the Supreme Court were presented as examples of a true democratic culture. For the political forces pushing for a higher degree of national recognition, or even secession, those events proved the democratic nature of secessionist aspirations in a modern state. If Canada, one of the most advanced and democratic countries in the world, was divisible in allowing Quebec to gain independence in the event of a favorable result in a referendum, any country that wanted to be called democratic would have to do the same. This axiom translates into the proposition that to be democratic, a country has to allow any subunit to secede in the event of a favorable referendum on the subject. ${ }^{\text {XxvII }}$ 
In Spain, admiration for the Clarity Act is widespread among the left of center and nationalist political parties as a standard that must be met in order to classify a constitutional system as democratic. The mantra of a "clear majority on a clear question" has been repeated for years without further explanation of what it really means or how would it be implemented in Spain. For its supporters, no true democrat could be opposed to the Clarity Act, as this instrument is the only viable tool to know the true will of the people on the question of secession. Hence, this Act results in a test of maturity for any system that defines itself as democratic.

This simplistic approach contains a reductionism of the Secession Reference to the obligation to negotiate, following the example of Quebec's sovereigntists. The Spanish nationalist forces have identified those notions of the Canadian experience that are most favorable for their cause, presenting them as the "Canadian parameter". The first one implies that it is possible and legitimate for a territorial subunit to conduct a referendum on secession. In Spain, referendums can only be called with the approval of the President, following article 92 of the Spanish Constitution. This legal difference between the two constitutional systems, together with the absence of a constitutional clause concerning the unity of the Canadian state, have been underestimated by some of the advocates of the Canadian experience. The second notion that has been highlighted by some of the advocates of this model is the duty to negotiate discussed above.

As López Basguren (2005: 12-14) remarks, these forces have consciously ignored important parts of the Canadian reality, creating their own vision and presenting it as if it were the Canadian model. This political discourse has benefited from the inaction of other political actors as, surprisingly, political parties opposing secession did not challenge this interpretation of the Canadian experience until some years ago. These parties left the monopoly of the "Canadian parameter" to the nationalist forces, which took advantage of this to create their own Canadian narrative.

As has been said above, the level of admiration for the Clarity Act varies across the political spectrum. In general terms, it is higher among parties that consider themselves to be to the left of center. These political formations have tried to find a balance between the principles of democracy and legality that could result in the recognition of the possibility of holding a referendum on secession within the current constitutional framework. Parties from the center to the right usually prioritize the principle of legality, stating that there 
cannot be democracy without respect for the rule of law and the constitutional order. Among nationalist parties the interest in the Clarity Act is also high, but with a different perspective. These formations, especially those in Catalonia, tend to emphasize the value of democracy, as the centerpiece of their political discourse. They have created the term "derecho a decidir" (right to decide) that basically hides within it a right to self-determination (López Basaguren 2016: 166-171). In their view, the democratic principle must prevail over others, as there is no bigger power that the will of the people expressed in a referendum. This conception entails a notion of hierarchy among constitutional principles, democracy being a value superior to the others, an aspect that was expressly rejected in the Canadian Supreme Court Reference. ${ }^{\text {xxvIII }}$

In the first group, we find the traditional position of the PSC (Partit dels Socialistes de Catalunya), the sister party of the Socialists (PSOE) in the Autonomous Community of Catalonia. For this formation, the Clarity Act is a federalist tool that can be used to address secessionist claims. The PSC defends a federal reform of the Spanish Constitution, a Clarity Act being an alternative in the event of that reform failing (Pascual 2016a). For the leader of the PSC, Miquel Iceta, the Canadian Clarity Act lacks clarity, as it does not specify which question and majority must be considered as clear (Pascual 2016b). In his view, a Clarity Act has the virtue of encouraging agreements between the parties in conflict making secession less likely due to the requirement of a reinforced majority on a clear question.

Although these postulates have been defended for years by the PSC, they have been abandoned in the last months as they created major tensions with the PSOE. ${ }^{\text {XIX }}$ The importation of the Clarity Act would mean the acceptance of the possibility of holding a referendum on secession, an aspect that is rejected by the majority of the PSOE. ${ }^{\text {xx }}$ However, for some socialist MPs like Odón Elorza, the enactment of a Spanish Clarity Act would make possible the combination of the principles of democracy and the rule of law (Elorza and Escudero 2015). In his proposal, Elorza structures the process in three tiers. To begin with, the Parliament of the Autonomous Community that wished to secede would have to approve a resolution in favor of a referendum by a reinforced majority. Secondly, the law would envisage that the central Government is obliged to call a nonbinding referendum on the issue, establishing the clarity of the question and the thresholds that would be needed to consider the result as clear. If these majorities were accomplished, the result would trigger good faith negotiations between the parties, in order to proceed 
with the separation via an amendment of the Spanish Constitution (Elorza and Escudero 2015).

In this proposal, we can clearly see the influence of the Canadian example, with some important variations. In the Canadian case, the question and the result are valued $a$ posteriori. In Canada, the provincial government sets the wording of the question and the Commons have 30 days to determine its clarity before the referendum, while in this case the wording of the question would be decided by the national government, as the competent body to call the referendum. The number of votes that would constitute a clear majority would also be established before the referendum, in contrast with the Canadian case where it is a matter that has to be decided by the House of Commons after the vote.

Center right parties such as the People's Party (PP) and Ciudadanos are totally opposed to secession and to the possibility of holding a referendum, an aspect that they consider as a breach of the constitutional order (Tudela Aranda 2016: 479). For these organizations a Clarity Act is not a viable instrument to reduce secessionist tensions because it would legitimate secessionist aspirations and could result in the dynamic of a neverendum. ${ }^{\mathrm{XXX}}$

The nationalist parties represented in the Spanish Parliament tend to be favorable towards a Clarity Act, or at least, to their own interpretation of it. The Basque Nationalist Party (PNV) has expressed its position in favor of the act, as it would allow the democratic expression of the people through a referendum ${ }^{\mathrm{XxxI}}$. The PNV also notes that the notion of clarity should be developed and included in the law, in order to reduce the possibility of a conflict over the interpretation of the results of an eventual referendum. The Catalan sovereigntists, particularly PDECat (formerly $\mathrm{CiU}$ ), used to take great interest in the Canadian case, frequently drawing parallels between Quebec and Catalonia. Their interest in the Clarity Act was high in the past, but has fallen in the last couple of years since they started to push for unilateral secession. As has been mentioned, their focus was on the democratic principle, from which they derived a right to self-determination. In their offers to the national government, in order to agree on the terms of a referendum, the Catalan parties -grouped in a collation called Junts Pel Sí (Together for Yes) - centered their agenda in the negotiation process after the vote, disregarding the notions of clarity. A good example of this was the unofficial referendum that they called in 2014 that will be discussed further below. 
The postulates of the new left-wing party, Podemos, are difficult to classify in the typology of these groups. Although the party has a strong leftist ideology, it has formed alliances in the Basque Country, Galicia and Catalonia with other formations with a strong nationalist component. As a result, its position regarding secession tends to differ from one territory to another. Their national leader, Pablo Iglesias, has stated that they support the derecho a decidir, in line with other nationalist political parties, but without any breach of constitutional legality. ${ }^{\text {xxIII }}$ During the Basque electoral campaign in 2016, Podemos proposed a Basque Clarity Act to regulate any future referendum that redefined the status of the Basque Country. This bill would include provisions regarding the wording of the question and the size of the majority needed with the objective of reducing uncertainty and increasing the transparency of the process (Gorospe 2016). The legal instrument proposed by Podemos only concerned the Basque Parliament, without any further explanation as to how the result would be implemented, or if it would trigger any negotiations with the national government. This proposal seemed to be an effort to attract nationalist voters during the campaign as, so far, this political formation has not introduced any bill related to the issue and it seems that they do not plan to do so in the near future.

\subsection{Getting it wrong: reality versus myth ${ }^{\mathrm{XxxIV}}$}

As we can see, the deifying of the Canadian example is, for the most part, based on a misreading of the Secession Reference, only taking into account certain passages while disregarding others. The emphasis tends to be placed on the quantitative clear majority test, discussing what percentage should be established as the threshold needed to trigger negotiations to allow secession. The Canadian Supreme Court referred to this test not just as a quantitative matter, but also as a qualitative evaluation. This last consideration is almost absent in the Spanish literature or in the political discourse, as if it never existed.

The question that thus arises is the following: why is qualitative analysis absent for the much praised "Canadian parameter" in the Spanish debate? In my view, the answer lies in the fact that this analysis could become a counter argument for those in favor of secession. To take qualitative elements into consideration, we have to take a closer look to aspects such as the distribution of support of the secessionist cause across the territory, the presence of minority groups or the degree of turnout in the event of a referendum. These three aspects tend to perform a role that does not play in favour of the secessionist 
movement. Taking the vote for nationalist parties as an indicator of support for the secessionist cause, we find that there is a substantial difference in popular support for this option between certain parts of the territory (e.g. Álava and its capital, Vitoria, in the Basque Country or the cities of Badalona and Tarragona in Catalonia). ${ }^{\mathrm{xxV}}$ The presence of minority communities, like the linguistic minority in the Val d'Aran in northwest Catalonia, cannot be disregarded, as their interests need to be preserved. ${ }^{\text {XxxvI }}$ Turnout is also an important element, as part of the population could express their rejection of the secessionist option by abstaining, if they consider the consultation to be illegal or illegitimate. ${ }^{\text {XXXVII }}$ In the event of a referendum on secession, qualitative aspects like these could have a decisive role in considering whether the result is clear or not.

Another point that is often misunderstood is the obligation to negotiate. In Spain, this duty tends to be characterized, particularly by those in favor of the derecho a decidir, as an obligation for the rest of the state to allow the subunit to secede. Hence, for these actors, the negotiation should be about the details of secession and not about secession itself, an aspect that they take for granted. This interpretation clearly contradicts the opinion of the Supreme Court in the Secession Reference. For the Court, the conduct of the parties in the negotiation process should be governed by the same principles that gave rise to the duty to negotiate. ${ }^{\text {XxVIII }}$ Those principles imply a rejection of the proposition that there is a legal obligation to accede to secession, as this would mean that the subunit would dictate the terms of the proposed secession, thereby nullifying the process of negotiation. ${ }^{\text {xxxIx }}$ At the same time, the federal government could neither refuse to enter into negotiations, nor conduct them in such a way that would suppose a complete denial of Quebec's rights, as this would give some legitimacy to the demands for a unilateral process. Therefore, the Supreme Court created a duty to negotiate in good faith, excluding the extreme positions of both parties, although this duty might indeed result in the secession of the territorial subunit.

In Spain, there seems to be a high degree of confusion between the obligation related to the means, the negotiation process as created by the Supreme Court, and an obligation related to the objective, which is the one desired by Quebec's sovereigntists. The negotiation process is not about the logistics of secession, as is commonly understood in Spain, but about the whole issue of secession. The content of the agreement that would result from these negotiations, or even the failure to reach one, is an issue for both parties 
to determine without either ruling out the possibility of secession, or taking it for granted. The confusion existing in Spain about the duty to negotiate could have its roots in the fact that the Canadian model has long been defended by nationalist parties that were the first to present the "Canadian parameter" as a solution to their secessionist claims. As they were the pioneers in recurring to the Canadian experience in the political arena, their interpretation has become dominant.

It is also interesting to note that the misreading of the Secession Reference, and the misinterpretation of the Canadian experience, is not limited to politics. The Spanish Constitutional Court, in its STC 42/2014 judgement, briefly cited the opinion of the Canadian Supreme Court on the issue of Quebec's secession in support of its own rejection of the possibility that an Autonomous Community could unilaterally call a referendum of self-determination (Fossas Espadaler 2014: 287-288). This prohibition, together with the conclusion that a region cannot secede unilaterally, was inferred from the principle of sovereignty. ${ }^{\mathrm{XL}}$ The recourse of the Spanish Constitutional Court to the Canadian experience is confusing, because sovereignty is not among the principles used by the Canadian Supreme Court and, as a consequence, the comparison is not accurate (Ferreres Comella 2014: 581). Furthermore, Canada's Supreme Court did not question the legality of the first step -the referendum- but the legality of the final act of purported unilateral secession. ${ }^{\text {XLI }}$ The Canadian Supreme Court declared that unilateral secession could not be the result of a unilateral referendum, but did not rule on the constitutionality of the referendum itself. Hence, it is not possible to draw parallels with the Canadian experience on the referendum issue, because this aspect was not controversial in Canada as provincial competence to call the referendum was taken for granted. XLII

All things considered, it seems clear that Spain's Constitutional Court misconstrued the Canadian reality, and referred wrongly to it as a comparative argument to justify the unconstitutionality of the Catalan Declaration of Sovereignty and the subsequent referendum (Fossas Espadaler 2014: 284; Solozábal Echevarría 2015: 46). By doing so, the Constitutional Court made the same incomplete interpretation that politicians often do, a mistake that should be avoided by the maximum interpreter of the Constitution.

Returning to the Clarity Act and its impact on secessionist processes, it should be recalled that the biggest virtue of the act is that it establishes a set of rules to address a referendum on secession. These rules should have an impact on the body that wants to 
hold the referendum, as it would need to respect them in order to be able to enter into negotiations in the event of a victory of the secessionist option. This reasoning should lead us to think that those political parties that have tried to call a referendum on the issue in Spain would have abided by them, in order to increase their legitimacy and gain support for their cause. However, their defense of the virtues embodied in the Clarity Act has been limited to theoretical considerations, but not to their political action. So far, there have been two attempts to hold referendums on issues like secession, sovereignty or redefining the political status of an Autonomous Community.

\subsubsection{Ibarretxe's plan and the status of the Basque Country}

The first case was the project of a new Statute of Autonomy for the Basque Country passed by the Basque Parliament in 2004. This project, commonly known as Plan Ibarretxe after the political leader of the Autonomous Community at the time, was presented as a legal document inspired by the Canadian model. The Basque Government often mentioned the Canadian experience during its defence of the plan, and the Preamble of the proposed Statute of Autonomy included "the compromise of not exercising unilaterally the right to self-determination" and "the obligation to negotiate with the Spanish State". XLIII These two formulations were clearly borrowed from the opinion of the Canadian Supreme Court in the Secession Reference, but they were manipulated in order to meet the political needs of the political parties supporting the new legal framework.

Article 13 of the proposed statute regulated the possibility of holding a referendum on a new political relationship between the Basque Country and the rest of Spain. ${ }^{\text {XLIV }}$ According to the provision, an absolute majority of the total of valid votes would be considered as a clear expression of will. In practice, that meant that the plebiscite could be won with just $50 \%+1$ vote. In a consultation with two options to choose, yes or no, the absolute majority is equal to the majority of votes as the winning option is always going to have a support over $50 \%$. Therefore, this article established the simple majority rule as the winning formula. This formula fails to respect any notions of clarity based on the Canadian model, as it could in no way be considered a clear majority. Again, the qualitative parameter of the majority test was absent, making it evident that this element is absent from the "Canadian parameter" as used in Spain. 
Furthermore, the same article added that in the event of such support being achieved, a negotiation process should be started in order to materialise the will of the people. That legal provision implied that negotiations must lead to a change in the political status of the Basque Country, as a sort of automatic process with no other options or issues to be discussed. This conception of the negotiation process was also very different from the one envisaged by the Canadian Supreme Court. The Court characterised the negotiations as difficult, highlighting that their result was uncertain and for the political actors to determine. The almost automatic result envisaged by the Basque Parliament was closer to the position of the Parti Québécois, which also thought that the only possible outcome of negotiations was for the secession of Quebec.

Although the whole process was inspired by the Canadian experience, the provisions of the proposed Statute of Autonomy related to the referendum were based on a biased reading of the Secession Reference. The articles regarding the formula for victory, and the subsequent negotiations, were incompatible with notions of clarity that inspired the Clarity Act. Also, the reference to the "Canadian parameter" seemed to be a mere marketing strategy in order to give a comparative legal basis to the project of reform. In any case, the project failed in early 2005 when the Spanish Parliament rejected it with an overwhelming majority of 313 to 29 , with two MPs abstaining.

Three years later the Basque Government again recurred to the Canadian experience to find a legal basis for a new formulation of the derecho a decidir, but the plan failed after the Constitutional Court, in STC 103/208, rejected this formula (Ridao 2014: 103-105). ${ }^{\text {XLV }}$

\subsubsection{Catalonia and the $9 \mathrm{~N}$ consultation}

Recourse to the Canadian process as a factor of legitimacy has also been a feature in Catalonia. In this region, the political struggle tends to be about the possibility of holding a referendum on secession. In this context, the "Canadian parameter" is presented as a model of democracy. For those who share this view, the 1980 and 1995 referendums in Quebec are examples of the true democratic nature of the Canadian constitutional system, as it allowed the consultation of the Quebec electorate on the issue of sovereignty. Following this reasoning, the rejection by the central government of the possibility of holding a referendum shows a lack of democratic culture that legitimatizes the recourse to unilateralism. 
In 2014, the Catalan government called for a referendum on the political future of Catalonia. As it was declared unlawful by the Spanish Constitutional Court, the Catalan government -with the aid of thousands of volunteers- conducted a participatory process designed to be like a referendum. This participatory process took place on November 9 2014 and consisted of a double question in which the second part was subordinated to the answer given in the first one. Those questions were originally designed for the referendum that was suspended by the Constitutional Court, but were carried over into the participatory process. These were:

\section{a) Do you want Catalonia to become a State? (Yes or No)}

If the answer is in the affirmative:

b) Do you want this State to be independent? $(\text { Yes or No })^{\mathrm{XLVI}}$

As we can see, the questions were anything but clear. The first concerned the possibility of Catalonia becoming a State. There was no mention of what was understood by the term State. It could be inferred from the second question that answering yes to the first one did not imply voting for secession as this issue was reserved for the following question. Therefore, if that State was not independent, what would be meant by voting yes to the first question and no to the second? This could include a wide range of possibilities that were not specified in the ballot, and could not be determined alone by the people of Catalonia, as a federal reform of the Spanish Constitution, or the establishment of confederation or an associated state. ${ }^{\text {XLVII }}$ The ambiguity of the question and its lack of clarity also had consequences in the process of interpreting the results (Castella Andreu 2014: 232). There were three possible ways of filling the ballot (no, yes/yes and yes/no) plus the option of just answering one question and leaving the other blank. The issue of secession was contained in the second question, but the results had to be interpreted in relation to the first question, adding complexity to the process of evaluating the existence of a clear majority. Also, as there was no official census, no turnout figure could be calculated, an aspect that rendered it impossible to take into account the qualitative aspects of the result. ${ }^{\text {XLVIII }}$ 
The participatory process conducted in Catalonia in 2014 perfectly illustrates the biased and partial interpretation that tends to be made of the Canadian experience in Spain. Some parts of the "Canadian parameter" were used as a tool to increase the legitimacy of demands for a referendum, while others, notably those related to the Clarity Act, were ignored, as they were not convenient for the secessionist cause. The participatory process did not meet any of the notions of clarity established by the Canadian Supreme Court and, hence, would not have satisfied the requirements of the Clarity Act.

\section{Migration and its limits: lessons from the Canadian experience}

The two examples discussed above are illustrations of how, in Spain, the Canadian reality has been distorted in order to serve the interests of certain political parties. The Canadian experience is a compact that contains several elements that cannot be separated from each other. The selective use of some of those elements, while ignoring the others, has been common in Spain for some time.

The Canadian experience offers plenty of lessons that could be useful to address the secessionist claims that Spain is currently experiencing, but they need to be put in context within the constitutional reality. In my view, becoming obsessed with importing foreign ideas to solve domestic problems is a mistake. Canada is a good comparative case to study how other countries have reacted to secessionist tensions in their own territory, but the Canadian model cannot be separated from the Canadian constitutional framework. The foundations of some of the elements of the Canadian experience that have been frequently quoted by the Basque and Catalan nationalists reside in the constitutional structure of the Canadian system, which is very different from the one present in Spain.

First of all, Canada is a federal entity while Spain, although it presents some federal elements, is a decentralized state where the subunits are not sovereign bodies. ${ }^{\text {XLIX }}$ One of the myths that are often cited by those in favor of the derecho a decidir is that the Canadian government agreed to the referendums in Quebec. If we take a closer look at the Canadian Constitution we will see that the power to conduct referendums is absent. ${ }^{\mathrm{L}}$ Canada follows the British model with a Westminster system of government, and the figure of referendums is considered alien to the British tradition, as these systems are based on the doctrine of 
parliamentary sovereignty (Dicey 1915: 78). In contrast, as was said above, referendums are regulated by the Spanish Constitution and must be called by the central Government.

A second feature is that Canada lacks a constitutional clause declaring the territorial integrity of the state. The absence of this constitutional provision allowed the Supreme Court to declare that Canada is divisible under certain circumstances. ${ }^{\text {LI }}$ These circumstances are those regulated by the Clarity Act, notably the existence of a clear majority on a clear question regarding the secession of a province from the rest of Canada. As Stéphane Dion has stated in several of his conferences in Spain, a mechanism of the type established in the Clarity Act is incompatible with the existence of a constitutional clause declaring the indissoluble unity of the Spanish nation. ${ }^{\text {LII }}$

Regarding secession, the Canada-Quebec dynamic is an anomaly, a democratic exception, which cannot be considered as a general trend. ${ }^{\text {LII }}$ The anomaly of the Canadian case does not, however, mean that it is not a valuable experience. The Canadian model was useful in Canada in a particular political context. Although there is no clear evidence that the Clarity Act has contributed to settling the issue of Quebec's independence, it was a turning point on the issue of secession. For the first time, the Canadian federal government acknowledged the possibility of entering into negotiations regarding the secession of a province, but it conditioned them to the existence of a clear majority on a clear question. The establishment of these conditions also had an influence on the secessionist camp, as the legitimacy of their cause was subordinated to the achievement of these conditions. Otherwise, the process would be considered as unlawful and the international recognition of the state would be compromised due to the unilateral nature of the process of secession.

The Canadian model is useful as a comparative example, but it has to be taken as a compact in order to be able to learn from the experience. Focusing on just one aspect, or making biased interpretations as some politicians do in Spain, is a mistake. Contrary to the general perception in Spain, the Canadian experience has more to offer to the federalist cause that to those pushing for secession. It underlines some of the weaknesses of the secessionist strategy, especially when it is confronted with a clear legal framework to respond to a secessionist challenge.

In 1980 and 1995 the federal government was on the defensive, always having to react to the movements of the secessionists. After the traumatic experience of the 1995 referendum the federal government went on the offensive and settled the terms of the 
quarrel with the Clarity Act. In Canada, but also in Spain, the secessionist parties are the champions of ambiguity, and attempt to take advantage of such situations to pursue their ends, disregarding any legal notion, with the defense of the democratic principle as their justification (Tornos Mas 2014: 47-48). Thanks to the Clarity Act, the secessionist movement can no longer claim that their democratic rights are violated or that their will is not respected. The disappearance of ambiguity and its replacement with the notion of clarity is one of the biggest lessons of the Canadian experience. The notion of clarity, and the subsequent duty to negotiate in good faith, have deactivated the unilateral path to secession, and the recourse to ambiguous questions aimed at influencing the electorate, together with the defense of the simple majority rule as a model of democracy. These instruments, defended by the Parti Québécois in 1980 and 1995, are no longer accepted. Since the Clarity Act, secessionists must abide by the procedure established in that act; otherwise the federal government will refuse to enter into negotiations on secession (Dion 2014: 34-36).

\section{Concluding remarks}

Once the impact of the Clarity Act on the Spanish political system has been assessed, a debate about the effect of such an act in Spain arises. What would be the consequences of the implementation of a Clarity Act in Spain? Would they favor the unity of the state or, by contrast, would they help the secessionist cause?

Trying to measure the impact of the transplant of the Clarity Act into the Spanish constitutional system is no easy task. The choice of the metaphor of the transplant instead of that of migration is no casual coincidence. ${ }^{\text {LIV }}$ Implementing an act such as the Canadian Clarity Act in the Spanish legal system is a very invasive operation with a high risk of rejection. Although its values are useful, the nature of the Clarity Act is very different from the legal foundations of the Spanish constitutional system.

Transplanting the Clarity Act would imply important concessions by the central government. First, it would mean that holding a referendum on secession is possible, a scenario that has been denied by all governments to date. To overcome this difficulty, we could imagine a political compromise between the central government, and its counterpart in the Autonomous Community, to hold a referendum in order to know the will of the 
people regarding the issue of secession. The transfer of the competence to conduct referendums to the autonomic government has also been suggested as an alternative. ${ }^{\mathrm{LV}}$ Secondly, it would also imply that article 2 of the Spanish Constitution relating to the indivisibility of the state should be amended, or at least reinterpreted, in order to make Spain divisible. ${ }^{\mathrm{LVI}}$

As these two considerations seem highly unlikely in the current political context, the impact of a Clarity Act should be limited to the values that the Canadian experience contains, but not to the act itself. Notions of clarity could be useful in the context of a non-binding referendum authorized by the central government to know if the people of an Autonomous Community want to cease to form part of Spain. Applying this concept to the wording of the question would assure that the result represents the true will of the people, and that it has not been influenced by a biased stetting of the question as in 2014 in Catalonia.

As has been said above, the concept of a clear majority is the one that has had the greatest impact upon the Spanish political landscape. An ambiguous formulation like the one in the Clarity Act is unlikely in Spain, as most actors have expressed their preference for a complete regulation of the issue. An illustration of this, although it was not an enlarged majority, is the aforementioned provision of the project of Statute of the Basque Country regarding a referendum on its political relationship with Spain.

Setting the minimum required percentage in favour before a referendum could help to evaluate if its result is clear or not, as there would be clear rules to decide what would constitute a clear majority. But this presetting of a clear majority entails the risk of subordinating the whole process to this issue, thereby conditioning the final result. As much as the wording of the question can influence the electorate, the presetting of a majority threshold can do so as well. If the achievement of that enlarged majority seems unlikely some voters could be tempted to vote for that option in the hope that it would translate into a higher degree of autonomy. Also, this factor could exacerbate secessionist tensions with the intention of mobilizing the electorate in order to achieve the required level of support. As a consequence, this could make secession more likely.

The duty to negotiate is also an important value that should be taken into account. Negotiations are an essential element of politics, and any effort to address a threat of secession must involve such a process. Contrary to the conceptualisation that those in 
favour of secession tend to make, this duty does not comprise an obligation to negotiate the details of secession, but an obligation to negotiate the whole issue that might, or might not, lead to secession. If we take it in broader terms, this value enshrines an obligation to address the problem of secession, an obligation to recognise that there is a part of the population that is discontent with the political arrangement currently in place, and that desires a change. This negotiation could result in the amendment of the Constitution in order to accommodate certain national or regional sensibilities. In this sense, the duty to negotiate could be seen as a test of the maturity of any democratic system, which has to adapt to address certain challenges even if those put into question the constitutional framework in place. This conception of the duty to negotiate is useful, even for those political forces that are opposed to secession, and that often do not pay much attention to the Canadian model. As said before, the Canadian experience contains more lessons against the secessionist cause than in favor, but they have been silenced due to the lack of interest of these political actors.

All things considered, it would be good for Spain to develop its own framework to respond to secessionist challenges, instead of copying the Canadian experience. Even though transplanting the Clarity Act does not seem a good choice, its inherent notions are a good starting point, but they need to be adapted to the constitutional architecture of the Spain. Enacting a legal framework to address secessionist claims will help to reduce tensions between both levels of government, delegitimising the recourse to a unilateral path to secession. It will also enhance cooperation between governments, as the political agenda would not be focused only on secession.

The aforementioned values of the Canadian experience have helped to decrease the uncertainties and ambiguities of the process and could be useful in the drafting of a Spanish model. Furthermore, by articulating its own legal framework Spain could implement elements such as a cooling down clause that are not present in the Canadian experience. ${ }^{\text {LVII }}$ This clause would prevent the neverendum dynamic that was mentioned before. Other elements like the requirement of a higher quorum than for ordinary constitutional amendment or sub-territorial ratification could also be considered. ${ }^{\text {VVIII }}$

Nevertheless, an exclusive focus on the issue of referendums is a mistake, as there are other factors that need to be assessed. The lessons of the Canadian experience are useful with regard to the matter of referendums and the legitimacy of unilateral secession, but 
there is a bigger picture. If Spanish institutions want to redirect the situation and reduce support for sovereignty in Catalonia, they must address other issues such as the distribution of competences, the distribution of finances, and an acknowledgment of national sensibilities in the Constitution. Secession is a hard case, and there are no easy ways to resolve it. Bold actions and a comprehensive legal framework are good tools to begin with but their utility is doubtful if there is no political will to find a compromise.

\footnotetext{
* PhD Candidate, University of the Basque Country (Spain). LLM in Constitutional Law at the Centro de Estudios Políticos y Constitucionales, Madrid (Spain) after graduating in Law and Business Management at the University Carlos III of Madrid. His main research interests are Canadian federalism and the politics of secession. He is the author of 'Senado y sistema federal en Canadá: cimposibilidad de una reforma deseable?' (Revista de Estudios Politicos, 2016). Email: franciscojavier.romero@ehu.eus. This paper was presented at the Symposium on The Constitution of Canada: History, Evolution, Influence and Reform, Scuola Superiore Sant'Anna, Pisa, 24 May 2017. The author would like to thank the conveners for their work and hospitality in Pisa.

I Vid. Dworkin (1975) \& (1978): 81. For Dworkin, hard cases are those that are not easy to solve for the judge because they cannot be resolved by the use of an unequivocal legal rule, set out by the appropriate body prior to the event. In these cases, principles play a crucial role in order to help the judge to settle the case. The issue of secession constitutes a hard case as there is no rule, unequivocal or not, to decide the case. Because of this, the Canadian Supreme Court recurred to the implicit principles that underlie the Constitution to establish a mechanism to address the secessionist demands of part of the Quebec population.

II The indivisible character of the state is present in the constitutions of France (articles 1 and 89), Italy (article 5), Brazil (article 1), Mexico (article 2) or Norway (article 1). Even a state born out of secession like Kosovo defines itself as indivisible according to article 1.1 of its constitution. In this sense, we can also recall a passage of the United States Supreme Court in Texas v White US 700, 725 (1869) affirming that "the Constitution $[\ldots]$ looks to an indestructible union, composed of indestructible states".

III As Mancini (2012: 481) notes, secession is at once the most revolutionary and the most institutionally conservative of political constructs. This duality reflects the complexity of this phenomenon as it could constitute a great challenge to state sovereignty, but it also can be an incentive to reinforce the latter in order to avoid the dismemberment of the state.

IV The Spanish Constitutional Court ruled in the STC 42/2014 that "la Constitución atribuye con carácter exclusivo la titularidad de la soberania nacional al pueblo español" [The Constitution exclusively attributes the ownership of national sovereignty to the Spanish people], rejecting the consideration of the Catalonian people as sovereign as it constitutes only a fraction of the Spanish people.

v Reference Re Secession of Quebec [1998] 2 SCR 217, hereafter Secession Reference.

VI The Parti Québecois and the Bloc Québécoishave openly criticized the act since its passing. In 2013 the BQ filed a motion to repeal it, but it was rejected by 283 to 5 in the House of Commons. Scholars like Pérez Tremps (2004: 53-55), Taillon (2014: 13-59), Rocher and Verrelli (2003: 220-232) and Haljan (2014: 379-380) have also stressed the ambiguities of the Clarity Act.

VII Several political parties have expressed their support to the idea of importing the Clarity Act. This is the case, among others, of the PNV (Congreso de los Diputados 2014: 40), the PSC (2016a: 9) or JxSí, the collation between CiU and ERC, (Hernàndez and Tomàs 2016).

VIII Russell characterizes as a constitutional odyssey the quest to bring the Constitution home from the United Kingdom -patriation - and the subsequent efforts to integrate Quebec back in the constitutional consensus after it was left out in 1982. For an overview of this period vid. Russell (2004: 107-227), Oliver (2005: 160184) and Stein (1997: 307-338).

Ix The questions raised were: 1) Under the Constitution of Canada, can the National Assembly, legislature or government of Quebec effect the secession of Quebec from Canada unilaterally? 2) Does international law give the National Assembly, legislature, or government of Quebec the right to effect the secession of Quebec from Canada unilaterally? In this regard, is there a right to self-determination under international law that would give the National Assembly, legislature, or government of Quebec the right to effect the secession of Quebec from Canada unilaterally? 3) In the event of a conflict between domestic and international law on the right of the National Assembly, legislature, or government of Quebec to effect the secession of Quebec from
} 
Canada unilaterally, which would take precedence in Canada?

$\mathrm{x}$ Secession Reference, para 52. This doctrine was created by the Judicial Committee of the Privy Council in Edwards v. Attorney-General for Canada, [1930]A.C. 124 (P.C.), p. 136 and has been revisited by the Supreme Court in cases such as Reference re Same-Sex Marriage, [2004] 3 S.C.R. 698, 2004 SCC 79, paras. 22-26 or Canadian Western Bank v. Alberta, [2007] 2 S.C.R. 3, 2007 SCC 22, para 23.

XI Secession Reference para 32.

XII Secession Reference para 49.

XIII The Court concluded that Quebec was outside of the scope of the situations where international law grants a right to external self-determination, as it was not a colony, its people were not oppressed and were not denied a meaningful access to government to pursue their political, economic, social and cultural development (Secession Reference para 138). For a detailed analysis see Woehrling (1999: 405-436).

XIV Secession Reference para 87.

xv Secession Reference para 88.

XVI "An Act to give effect to the requirement for clarity as set out in the opinion of the Supreme Court of Canada in the Quebec Secession" Reference S.C. 2000, c. 26.

XVII Secession Reference paras 87-92.

xVIII Following section 1(4) of the Clarity Act these are: (a) a referendum question that merely focuses on a mandate to negotiate without soliciting a direct expression of the will of the population of that province on whether the province should cease to be part of Canada; or (b) a referendum question that envisages other possibilities in addition to the secession of the province from Canada, such as economic or political arrangements with Canada, that obscure a direct expression of the will of the population of that province on whether the province should cease to be part of Canada.

XIX Although the Secession Reference does not contain a prohibition of asking about future arrangements, the notion of a clear expression of will seems to be in conflict with subordinating the answer to a future event that could or could not happen.

$\mathrm{xx}$ Secession Reference para 87.

xxi Secession Reference paras 73-76.

xxII "An Act respecting the exercise of the fundamental rights and prerogatives of the Québec people and the Québec State", (2000, chapter 46).

xxIII The judicial process started in 2001 when Keith Henderson, the leader of the Equality Party, impugned six articles of the Bill 99. Due to administrative problems the process was delayed for several years. In 2013 the government of Quebec and the federal government intervened to express their respective positions on the matter. Again, for administrative reasons, the ruling has been delayed and it should be rendered in 2018.

xxIV This policy was initiated by Lucien Bouchard when he became PM of Quebec in 1996, who affirmed that he would not call another referendum until the winning conditions -conditions gagnantes- were met, in other words, until the support for sovereignty was high enough to guarantee a victory of the secessionist option (Globe and Mail: 1999). The recently elected leader of the PQ, Jean-François Lisée, has also committed himself to this idea (Radio Canada: 2016).

xxv Related to this topic vid. Relaño Pastor (1999: 63-86), Oliveras i Jané (2001: 243-279) and Ruiz Vieytez (2006: 9-29).

xxvi As an example of this interest, vid. Bilbao Ubillos (1999): 83-118, Pérez Tremps (2004) and López Basaguren (2013): 53-92.

XXVII The former president of the Generalitat of Catalonia, Artur Mas, recalled this axiom by affirming that "Canada has much more respect for Quebec than Spain for Catalonia" Vallespin (2011).

xxvIII Secession Reference p. 221.

xxIx The reference to the Canadian model and the Clarity Act was erased from the PSC political manifesto in their XIII Congress held in Barcelona the $4^{\text {th }}$ and $5^{\text {th }}$ of November 2016. Vid. PSC (2016b: 12-13).

xxx PSOE (2017): 38.

xxxI The Canadian writer Josh Freed coined the term neverendum in relation with the repeated referendums in Quebec. He recalls the idea that once the first referendum has been held, subsequent referendums will be called until the victory of the secessionist option.

xxxII Europa Press (2014) - Bilbao, 11 th April 2014.

xxxiI Europa Press (2017) - Madrid, 1'st March 2017.

xxxiv The expression "Getting it wrong" is taken from Paul Romney's book: Getting it Wrong: How Canadians Forgot Their Past and Imperilled Confederation. In that book, Romney explains how Canadians once regarded the 
Confederation as a compact of peoples, the English and the French, but with the passing of time that conception evolved into a centralist myth of the origins of Confederation.

xxxv In the Catalan elections of 2015, the secessionist coalition JxSí obtained 39.59\% of the vote. This figure fell to $24.55 \%$ and $29.39 \%$ in the cities of Badalona and Tarragona, respectively. In the Basque elections of 2016 the PNV obtained $37.65 \%$ of the vote, while in the capital, Vitoria, it obtained only $25 \%$. In the province of Álava the vote for the winning party was $29 \%$.

XXXVI Around 30\% of the population of this valley in the Pyrenees Mountains has Aranese, an Occitan language, as their mother tongue.

XXXVII As it was the case in the unilateral, and thus illegal, referendum on secession held on October 1st 2017 by the Catalan Government despite it was suspended by the Constitutional Court.

xxxviII Secession Reference para 90.

xxxix Secession Reference para 91.

XL STC 42/2014 - Fundamento jurídico 3.

XLI Secession Reference par 86.

XLII Vid. note 49 below.

XLIII The original text, in Spanish, was "el compromiso de no ejercer unilateralmente el derecho de autodeterminación y el reconocimiento explícito de la obligación de abrir un proceso de negociación y pacto con el Estado".

XLIV The Basque government envisaged the Basque Country as a free state associated to Spain, in similar fashion to the sovereignty-association proposed by the Parti Québécois in 1980, and the new economic and political partnership in 1995.

XLV This plan was articulated through Law 9/2008, which contained provisions for a non-binding referendum to ask for a mandate to negotiate with the terrorist group ETA, and to conduct negotiations to design a new legal framework for the derecho a decidir. The preamble of the law made explicit references to the Secession Reference as a factor of legitimacy. As the referendum had an impact on sovereignty it was rejected by the Constitutional Court as it was a matter for the whole Spanish nation to decide on, not just a fraction of it.

XLVI As the questions were originally designed for the referendum, they were included in the Decree $129 / 2014$ of the Generalitat of Catalonia that was enacted under the provisions of the Law 10/2014. The Constitutional Court suspended both norms after they were challenged by the Central Government. Following the ruling of the Constitutional Court the Catalan Government decided to carry on the participatory process with the same questions designed for the referendum.

XLVII It should be noted that any change in the Spanish Constitutional framework regarding the territorial organization of the state must obtain the approval of the Spanish people in a referendum.

XLVIII The census was elaborated on a case-by-case basis with data of the electors that voted. Some organizations opposed to the secession process claimed that there cases of fraud due to this issue.

XLIX The federal nature of Canada was contested by Wheare (1963: 19-20), who described the Canadian constitution as quasi-federal, although he conceded that it was predominantly federal in practice. This statement is based on a literal reading of the Constitution, in particular those provisions regarding the power of disallowance and the federal appointment of lieutenant governors which conferred powers to the federal government that could undermine the authority of the provinces. However, this idea was rejected by the Supreme Court in the Secession Reference (para 55) highlighting the undisputed federal nature of Canada given the fact that these powers has been abandoned. This idea is shared by Hogg (2007: 5-19) and Monahan (2013: 84-85). In relation to Spain, it has been described by Watts (2009: 55) and Moreno (2007: 95-97) as " $a$ federation in disguise" because of the federalizing nature of the internal logic of the Estado de las Autonomias.

${ }^{\mathrm{L}}$ Quebec enacted its Referendum Act, chapter 64.1, in 1978 under the provincial residual clause regarding matters of merely local or private nature in the province of section 92.16 C. 1867.

LI Secession Reference para 84.

LII Conference at the Barcelona Bar on April 11th 2013 entitled "Secession and Democracy".

LIII In fact, in addition to the Canadian case, just two constitutions in the world, Ethiopia (article 39.1) and Saint Kits and Nevis (article 115), contain provisions regulating the right to secession.

LIV In relation with the metaphor, vid. Ewald (1995): 489-51, Nelken and Feest (2001) and Pegoraro (2013): 33-80.

LV The Government of Catalonia requested the transfer of this competence in 2014 through proposition 125/000013, but it was rejected by the Spanish Parliament. It must be noted that in its ruling 103/2008 the Constitutional Court considered that holding a referendum on secession is against the Constitution as the sovereignty belongs to the nation. Any consultation in that sense needs a previous reform of the Constitution 
in order to be compatible with it.

LVI As Aláez Corral (2015): 151-157 recalls, there are not any material limits on the Spanish Constitution and, therefore, its complete amendment is possible. For that reason, this article should not be considered as an impediment to include a secession clause in the Spanish Constitution.

LVII A cooling down-enfriamiento in the Spanish doctrine- clause refers to the entrenchment of a clause that bans the holding of a new referendum on secession for a period of time after one has been held with the aim of preventing a dynamic of continues referendums on the issue. This clause settles the debate for a period, allowing the electorate to reflect of the issue without the passions of the political debate.

LVIII See Haida Nation v. British Columbia (Minister of Forest), 2004 SCC 73. This territorial counting of the votes could be a tool to address the issue of different degrees of support for secession among the territory of a given Autonomous Community. The requirement of an enlarged majority would not just apply to the final result, but also to the result in each province that integrates the Autonomous Community that wants to secede. These elements have a qualitative nature in line with the reasoning of the Canadian Supreme Court. This instrument could also be used to protect minorities that are not concentrated in a sub-unit, like those resulting from immigration. In this sense, vid. Saénz Royo (2016: 145-148).

\section{References}

- Aláez Corral Benito, 2015, 'Constitucionalizar la secesión para armonizar la legalidad constitucional y el principio democrático en estados territorialmente descentralizados como España', Revista d'estudis autonòmics ifederals, no. 22: 136-183.

- Bilbao Ubillos Juan María, 1999, 'La secesión de Quebec', Cuadernos de Alzate: Revista vasca de la cultura y las ideas, no. 21: 83-118.

- Castellá Andreu Josep María, 2014, 'La Secesión Catalana, Entre la Política y el Derecho', Anuario Facultad de Derecho - Universidad de Alcalá VII, 227-240.

- $\quad$ Choudhry Sujit, 2006, The Migration of Constitutional Ideas, Cambridge University Press, Cambridge.

- Dicey Albert V., 1915, Introduction to the Study of the Law of the Constitution, $8^{\text {th }}$ edition, Macmillan, London.

- Dion Sthéphane, 2000, 'The Clarity Act Debate in the House of Commons', Canadian Parliamentary Review, XXIII(2).

- Dion Sthéphane, 2014, 'The Reference on Quebec Secession: a Positive Impact for All', Revue québécoise de droit constitutionnel, VI: 21-37.

- Dumberry Patrick, 2015, 'The Secession Question in Quebec', Diritto pubblico comparato ed europeo, XVII(2): 357-380.

- $\quad$ Dworkin Ronald, 1975, 'Hard Cases', Harvard Law Review, LXXXVIII(6): 1057-1109.

- Dworkin Ronald, 1978, Taking Rights Seriously, Duckworth, London.

- $\quad$ Ewald William, 1995, 'Comparative Jurisprudence (II): The Logic of Legal Transplants', The American Journal of Comparative Law, XLIII(4): 489-510.

- $\quad$ Ferreres Comella Víctor, 2014, 'The Spanish Constitutional Court Confronts Catalonia's "Right to Decide" (Comment on the Judgment 42/2014)', European Constitutional Law Review, X: 571-590.

- Fossas Espadaler Enric, 2014, 'Interpretar la política. Comentario a la STC 42/2014, de 25 de marzo, sobre la Declaración de soberanía y el derecho a decidir del pueblo de Cataluña', Revista Española de Derecho Constitucional, no. 101: 273-300.

- Haljan David, 2014, Constitutionalising Secession, Hart Publishing, Oxford.

- Hogg Peter W., 2007, Constitutional Law of Canada, Carswell, Toronto.

- Keating Michael, 2001, Nations against the State. The New Politics of Nationalism in Quebec, Catalonia and Scotland, Palgrave, Basingstoke. 
- López Basaguren Alberto, 2005, 'Stéphane Dion y las verdades silenciadas de la experiencia canadiense', in Dion Stéphane, La politica de la claridad. Discursos y escritos sobre la unidad canadiense, Alianza Editorial, Madrid.

- López Basaguren Alberto, 2013, 'Los referendos de secesión de Quebec y la doctrina de la Corte suprema de Canadá', in Saénz Royo Eva and Contreras Casado Manuel (eds), La participación política directa: referéndum y consultas populares, Comuniter, Zaragoza.

- López Basaguren Alberto, 2016, 'Demanda de secesión en Cataluña y sistema democrático. El procés a la luz de la experiencia comparada', Teoría y Realidad Constitucional, no. 37: 163-185.

- Mancini Susanna, 2012, 'Secession and Self-Determination', in Rosenfield, Michel and Sajó, András (eds) The Oxford Handbook of Comparative Constitutional Law, Oxford University Press, Oxford, 481-500.

- Monahan Patrick, 2000, 'Doing the rules: an assessment of the federal Clarity Act in light of the Quebec secession reference', Commentary - C.D. Howe Institute, 135 (Feb 2000): 1-39.

- $\quad$ Monahan Patrick, 2013, Constitutional Law, $4^{\text {th }}$ edition, Irwin Law, Toronto.

- Moreno Luis, 2007, 'Federalism in Multinational Spain', in Burgess Michael and Pinder John. (eds), Multinational Federations, Routledge, New York, 86-107.

- Murkens Jo E., Jones Peter \& Keating Michael, 2002, Scottish Independence, Legal and Constitutional Issues, Edinburgh University Press, Edinburg.

- $\quad$ Nelken David and Feest Johannes, 2001, Adapting Legal Cultures, Hart Publishing, Oxford.

- $\quad$ Oliver Peter C., 2005, The Constitution of Independence. The Development of Constitutional Theory in Australia, Canada and New Zealand, Oxford University Press, Oxford.

- Oliveras Jané Neus, 2001, 'El multiculturalismo’, in Castellá Andreu Josep María and Mitjans Perelló Esther (eds), Canadá: introducción al sistema político y jurídico, Universitat de Barcelona, Barcelona, 243-279.

- $\quad$ Pegoraro Lucio, 2013, 'Trasplantes, injertos, diálogos, jurisprudencia y doctrina frente a los retos del Derecho comparado', in Ferrer Mac-Gregor Eduardo and Herrera García Alfonso, Diálogo Jurisprudencial en Derechos Humanos, Tirant lo Blanch, Valencia, 33-80.

- Pelletier Benôit, 2001, 'La loi sur la clarté, sa contre partie québécoise, et le renvoi relatif à la sécession du Québec', Revue belge de Droit constitutionnel, no. 4: 513-533.

- Pérez Tremps Pablo, 2004, El marco (a)constitucional del debate sobre la secesión de Quebec, Punt de Vista, Barcelona.

- Relaño Pastor Eugenia, 1999, Multiculturalismo y derecho de libertad religiosa en Canadá, Anuario de Derecho Eclesiástico del Estado, no. 15: 63-86.

- Ridao i Martín Joan, 2014, 'La Juridificación del Derecho a Decidir en España. La STC 42/2014 y el derecho a aspirar a un proceso de cambio político del orden constitucional', Teoría y Realidad Constitucional, no. 91: 91-136.

- Rocher François and Verrelli Nadia, 2003, 'Questioning Constitutional Democracy in Canada: From the Canadian Supreme Court Reference on Quebec Secession to the Clarity Act' in Gagnon Alain-G., Gibernau Montserrat and Rocher François (eds), The Conditions of Diversity in Multinational Democracies, IRPP, Montreal, 207-235.

- Romney Paul, 1999, Getting it Wrong: How Canadians Forgot Their Past and Imperilled Confederation, University of Toronto Press, Toronto.

- Ruiz Vieytez Eduardo Javier, 2006, 'Canadá y el multiculturalismo. Un análisis crítico’, Revista de derecho migratorio y extranjería, no. 13: 9-29.

- $\quad$ Russell Peter H., 2004, Constitutional Odyssey: Can Canadians Become a Sovereign People?, University of Toronto Press, Toronto.

- Saénz Royo Eva, 2016, 'La Regulación del Referendo en el Derecho Comparado: Aportaciones Para el Debate en España’, Revista Española de Derecho Constitucional, no. 108: 123-153.

- Solozábal Echevarría Juan José, 2015, 'La sentencia sobre la Declaración soberanista y el derecho a decidir del pueblo catalán (STC 42/2014)’, El Cronista del Estado Social y Democrático de Derecho, no. 50: 46-49.

- $\quad$ Stein Michael B., 1997, 'Improving the Process of Constitutional Reform in Canada: Lessons from the Meech Lake and Charlottetown Constitutional Rounds', Canadian Journal of Political Science, XXX(2): 307-338.

- Taillon Patrick, 2014, 'De la Clarté à l'arbitraire: le contrôle de la question et des résultats référendaires par le Parlement Canadien', Revista d'estudis autonòmics i federals, no. 20: 13-59. 
- Tierney Stephen, 2004, Constitutional Law and National Pluralism, Oxford University Press, Oxford.

- Tornos Mas, Joaquín, 2014, 'El problema catalán: una solución razonable', El Cronista del Estado Social y Democrático de Derecho, no. 42: 44-53.

- Tudela Aranda José, 2016, 'El Derecho a Decidir y el Principio Democrático', Teoría y Realidad Constitucional, no. 37: 477-497.

- Watts Ronald, 2009, 'Spain: a Multinational Federation in Disguise?', in Tudela Aranda José and Knüpling Félix (eds), España y modelos de Federalismo, Centro de Estudios Políticos y Constitucionales, Madrid, $55-81$.

- Wheare K.C., 1963, Federal Government. $4^{\text {th }}$ edition, Oxford University Press, London.

- Woehrling José, 1999, 'El juicio del Tribunal Supremo de Canadá sobre la eventual secesión de Québec', Revista V asca de Administración Pública, no. 54: 405-436.

\section{Documentary sources}

- Congreso de los diputados, 2014, Diario de Sesiones del Congreso de los Diputados, X Legislatura, No. 192, p. 40 - 8 April 2014.

- Elorza Odón and Escudero Manuel, 2015, 'De la confrontación al diálogo: por una Ley de Claridad para España', El País, 23 $3^{\text {rd }} \quad$ September $2015 . \quad$ Available at http://politica.elpais.com/politica/2015/09/23/actualidad/1443030309 504520.html.

- $\quad$ Europa Press, 2014, 'PNV afirma que los nacionalistas vascos y catalanes no se oponen a una Ley de Claridad e insta a "definir los términos", 11 th April 2014. Available at http://www.europapress.es/nacional/noticia-pnv-afirma-nacionalistas-vascos-catalanes-no-oponen-leyclaridad-insta-definir-terminos-20140411131514.html.

- $\quad$ Europa Press, 2017, 'Pablo Iglesias, a favor de que voten todos los españoles en una consulta sobre Cataluña', 1st March 2017. Available at http://www.europapress.es/nacional/noticia-pablo-iglesias-favorvoten-todos-espanoles-consulta-cataluna-20170301104438.html.

- Gorospe Pedro, 2016, 'Podemos propone una Ley de Claridad para regular la consulta vasca', El País, 14 $4^{\text {th }} \quad$ September $2016 . \quad$ Available at http://politica.elpais.com/politica/2016/09/13/actualidad/1473764518 670974.html.

- Hernàndez Enric and Tomàs Neus, 2016, 'Entrevista al President de la Generalitat: Carles Puigdemont: "Podem negociar la data i la pregunta del referéndum"', El Periódico, 19th March 2016. Available at http://www.elperiodico.cat/ca/politica/20160319/carles-puigdemont-entrevista-4989397.

- $\quad$ Pascual Roger, 2016a, 'El PSC plantea un referéndum “a la canadiense” para Catalunya', El Periódico, 30 ${ }^{\text {th }}$ June 2016. Available at http://www.elperiodico.com/es/noticias/politica/psc-referendum-canadiensecatalunya-fracasa-reforma-constitucional-5239403.

- Pascual Roger, 2016b, ‘Por qué la ley de claridad canadiense no hace honor a su nombre?', El Periódico, 15 thJuly 2016. Available at http://www.elperiodico.com/es/noticias/politica/ley-claridad-canadaquebec-psc-5246153.

- $\quad$ PSC, 2016a, Ponència Política del XIIIè Congrés del PSC, June 2016.

- $\quad$ PSC, 2016b, Resolución Política XIII Congrés del PSC, November 2016.

- $\quad$ PSOE, 2017, Ponencia Marco 39 Congreso.

- Radio Canada, 2016, 'Lisée se lance et promet un premier mandat péquiste sans référendum', 16th May 2016. Available at: http://ici.radio-canada.ca/nouvelle/781729/jean-francois-lisee-candidat-directionparti-quebecois-referendum.

- Séguin Rhéal, 1999, 'Bouchard in no rush to call referendum', The Globe and Mail, Toronto, 18 ${ }^{\text {th }}$ December 1999.

- Vallespín, Ivanna, 2011, 'Artur Mas: “Canadá es más respetuoso con Quebec de lo que España lo es con Cataluña”, El País, 10 $0^{\text {th }}$ October 2011. Available at: http://elpais.com/elpais/2011/10/10/actualidad/1318234636 850215.html. 